\title{
Stability and uptake of methylphenidate and ritalinic acid in nine-spine stickleback (Pungitius pungitius) and water louse (Asellus aquaticus)
}

\author{
Erin S. McCallum ${ }^{1,2}$ (D) Richard H. Lindberg ${ }^{3} \cdot$ Patrik L. Andersson $^{3} \cdot$ Tomas Brodin $^{1,2}$
}

Received: 19 September 2018 / Accepted: 13 February 2019 / Published online: 25 February 2019

(C) The Author(s) 2019

\begin{abstract}
The presence of human pharmaceuticals in the environment has garnered significant research attention because these compounds may exert therapeutic effects on exposed wildlife. Yet, for many compounds, there is still little research documenting their stability in the water column and uptake in organism tissues. Here, we measured the uptake and stability of methylphenidate (Ritalin $囚$, a frequently prescribed central nervous system stimulant) and its primary metabolite, ritalinic acid, in (1) water only or (2) with nine-spine stickleback and water louse. Methylphenidate degraded to ritalinic acid in both studies faster at a higher temperature $\left(20^{\circ} \mathrm{C}\right.$ versus $\left.10^{\circ} \mathrm{C}\right)$, with concentrations of ritalinic acid surpassing methylphenidate after $48-100 \mathrm{~h}$, depending on temperature. The concentration of methylphenidate in stickleback was highest at the first sampling point (60 min), while the concentration in water louse tissues reached comparatively higher levels and peaked after $\sim 6$ days. Neither stickleback nor water louse took up ritalinic acid in tissues despite being present in the water column. Our findings provide valuable data for use in future risk assessment of methylphenidate and will aid in the design of studies aimed at measuring any ecotoxicological effects on, for example, the behaviour or physiology of aquatic organisms.
\end{abstract}

Keywords Pharmaceuticals $\cdot$ Ecotoxicology $\cdot$ Stimulant $\cdot$ Behaviour $\cdot$ Methylphenidate $\cdot$ Aquatic organisms

\section{Introduction}

The presence of pharmaceuticals in the environment has drawn widespread concern from researchers and environmental managers over the impacts that exposure to

Responsible editor: Philippe Garrigues

Electronic supplementary material The online version of this article (https://doi.org/10.1007/s11356-019-04557-9) contains supplementary material, which is available to authorized users.

Erin S. McCallum

erin.mccallum@slu.se; erin.s.mccallum@gmail.com

1 Department of Ecology and Environmental Science, Umeå University, 90187 Umeå, Sweden

2 Present address: Department of Wildlife, Fish, and Environmental Studies, Swedish University of Agricultural Sciences (SLU), 901 83 Umeå, Sweden

3 Department of Chemistry, Umeå University, 90187 Umeå, Sweden pharmaceuticals might have on, for example, antibiotic resistance and aquatic wildlife (Boxall et al. 2012; Brodin et al. 2014). Many pharmaceutical compounds are present in the environment, but attention on compounds that modulate human behaviour-such as antidepressants, anxiolytics, or stimulants - has recently grown (Calisto and Esteves 2009; Brodin et al. 2014; Saaristo et al. 2018). The biological targets of many pharmaceuticals are shared between humans and aquatic vertebrates (Gunnarsson et al. 2008). Therefore, unintended environmental exposure to pharmaceuticals in the wild may cause subtle changes to animal behaviour (e.g., predator avoidance, reproduction) that could have important and potentially detrimental effects on fitness in the wild.

One such compound with the potential to modulate behaviour is methylphenidate (e.g., Ritalin ${ }^{\circledR}$, Concerta ${ }^{\circledR}$ ): a central nervous system stimulant prescribed to promote executive functions such as attention and focus in humans. Methylphenidate is a commonly prescribed treatment for attention deficit hyperactivity disorder (ADHD), and the nonmedical, recreational use of methylphenidate has been increasing (McCabe et al. 2005; Chai et al. 2012). 
Methylphenidate increases dopaminergic and norepinephric transmission via inhibiting the reuptake of these catecholamines from the synaptic cleft (Volkow et al. 2002). Following a standard dose (18 $\mathrm{mg}$ ), up to $80 \%$ is excreted as ritalinic acid ( $\alpha$-phenyl-2-piperidine acetic acid) that has little pharmacological activity (Faraj et al. 1974; Concerta Prescribing Information 2013). Recently, Endres et al. (2017) showed that exposure to environmentally relevant concentrations of methylphenidate reduced cortisol (i.e., stress) and inhibited anxiety-like behaviours (e.g., freezing, hiding) in stressed zebrafish (Danio rerio). Reductions in anxiety behaviours have been noted in adult guppies (Poecilia reticulata) exposed to $250 \mathrm{ng} / \mathrm{L}$ (De Serrano et al. 2016) and in zebrafish exposed to a much higher concentration $(50 \mathrm{mg} /$ L) as embryos (Levin et al. 2011).

Methylphenidate has been detected in treated wastewater effluents at low concentrations $(<10 \mathrm{ng} / \mathrm{L})$, and this is, in part, because it is readily transformed before excretion (Letzel et al. 2010; van der Aa et al. 2013; Du et al. 2014; Watkins et al. 2014; Bean et al. 2018). However, in untreated wastewater, levels up to $1500 \mathrm{ng} / \mathrm{L}$ have been found (Burgard et al. 2013). The primary metabolite, ritalinic acid has been detected at concentrations ranging from 50 to $300 \mathrm{ng} / \mathrm{L}$ in treated effluent (Letzel et al. 2010; Burgard et al. 2013; Oliveira et al. 2015). Methylphenidate and ritalinic acid have low octanol-water partitioning coefficients; methylphenidate $(0.20)$ and ritalinic acid $(-1.1)$, and uptake occurs mainly from the water phase (US EPA EPISuite n.d.). Their predicted bioconcentration factors are, however, very low (3.2), which indicates low expected levels of these compounds in aquatic biota (US EPA EPISuite n.d.).

Given recent and growing research attention on methylphenidate and ritalinic acid as environmental pollutants, more detailed investigations of their stability in the water column and concentrations in the tissues of aquatic organisms are needed. Basic data on the stability of compounds in water and uptake in tissue is needed to effectively design laboratory tests. To support future studies on effects on aquatic organisms, we measured concentrations of methylphenidate and ritalinic acid in the water column under static laboratory conditions, with and without the presence of biota over 2 weeks. In our biota study, we measured the tissue uptake of both compounds in muscle tissue of the nine-spine stickleback (Pungitius pungitius) and whole-body homogenates of water louse (Asellus aquaticus) to compare uptake in a vertebrate and invertebrate. Both species are widespread in temperate freshwater environments in North America, Europe, and Asia, making these results ecologically relevant and widely applicable. We included a temperature treatment $\left(10^{\circ} \mathrm{C}\right.$ and $20{ }^{\circ} \mathrm{C}$ ) in this study to test how temperature affects the degradation of both compounds in the exposure environment and uptake in tissues.

\section{Methods}

\section{Preparation of stock solutions}

Stock solutions were prepared by dissolving methylphenidate hydrochloride (CAS 298-59-9; Merck Darmstadt, Germany) in crystalline form in Milli-Q ultra-pure water (Millipore advantage A10, Billerica, USA), acidified with $0.1 \%$ formic acid (Suprapur, Merck KGaA), and mixed for 5 min using an ultrasonic bath. The pKa of methylphenidate is 9.5 (SciFinder), and the stock solution was acidified to a $\mathrm{pH}$ of $\sim 2.7$ to keep the compound in the neutral form. The experiments were conducted at $\sim \mathrm{pH} 7$ conditions, which means that the level of the ionized form is negligible. The stock solution for study 1 (water only) was prepared on December 15, 2017, and the exposure began the next day. For study 2 (water and biota), the stock solution was prepared on January 29, 2018, and the exposures began on the same day.

\section{Study 1: static water only}

The stability of methylphenidate and breakdown to ritalinic acid was first measured in water without biota. A total of $1870 \mathrm{ng} / \mathrm{L}$ (nominal concentration) of methylphenidate ( $1 \mathrm{~mL}$ of the stock solution) was added to a glass aquarium filled with $20 \mathrm{~L}$ of ground water. The tank was aerated and kept at $20^{\circ} \mathrm{C}$ (ambient room temperature). Water was sampled at $0 \mathrm{~min}$ (immediately after dosing), $5 \mathrm{~min}, 15 \mathrm{~min}, 45 \mathrm{~min}$, $90 \mathrm{~min}, 4 \mathrm{~h}, 10 \mathrm{~h}, 24 \mathrm{~h}, 2$ days, 3 days, 4 days, 5 days, 7 days, and 12 days. This exposure was conducted in a windowless room with a light-dark cycle of 13L:11D.

\section{Study 2: static water + biota}

Nine-spine stickleback were collected using umbrella traps from ponds in Röbäck, Sweden, in July 2017. Fish were housed in a large, aerated, ground water flow-through tank $(1500 \mathrm{~L})$ until the start of the experiment. Fish were fed frozen chironomid larvae until satiation once daily. Water louse were collected using sweep nets from Djupsundsbäcken near Holmsund, Sweden, in January 2018. Water louse were kept in aerated containers with detritus (predominately alder leaf litter) until the start of the experiment.

Stickleback and water louse were exposed to $187 \mathrm{ng} / \mathrm{L}$ (nominal concentration) methylphenidate at two temperature treatments: $10{ }^{\circ} \mathrm{C}$ (in a climate chamber) and $20^{\circ} \mathrm{C}$ (ambient room temperature). Both exposures were maintained at the same light cycle used in study 1 . Organisms were exposed under static conditions using three replicate glass aquaria filled with $20 \mathrm{~L}$ water. The aquaria were equipped with an airstone and two ceramic clay pots for shelter in each temperature treatment. Fish were exposed in two tanks, while water louse were exposed separately in the remaining tank. Water from each tank was 
sampled at $0 \mathrm{~min}$ (immediately after dosing), $15 \mathrm{~min}, 30 \mathrm{~min}$, 60 min, 4 h, 8 h, 24 h, 3 days, 5 days, 7 days, 9 days, 10 days, 11 days, 12 days, and 13 days. Three to six water louse and three to six fish were sampled at each of the following time points: 60 min, 4 h, 8 h, 24 h, 3 days, 5 days, 7 days, 9 days, 10 days, 11 days, 12 days, and 13 days. Fish were euthanized via cerebral concussion and spinal severance. Water quality measures of $\mathrm{pH}$ (Merck pH Universal Indicator Strips), dissolved oxygen, and temperature (YSI Pro DO Series) were verified in the exposure tanks on the final days of sampling. For the low $\left(10^{\circ} \mathrm{C}\right)$ and high $\left(20^{\circ} \mathrm{C}\right)$ temperature rooms, respectively, water temperature was (mean \pm s.d.) $10.03 \pm 0.32{ }^{\circ} \mathrm{C}$ and $17.07 \pm 0.21{ }^{\circ} \mathrm{C}$; dissolved oxygen was $14.40 \pm 0.27 \mathrm{mg} / \mathrm{L}$ and $12.30 \pm 0.30 \mathrm{mg} / \mathrm{L}$; and there were no changes in $\mathrm{pH}(7 \pm 0$, for both temperatures).

\section{Chemical analysis}

Immediately after sampling, all water and organisms sampled were frozen at $-20{ }^{\circ} \mathrm{C}$ until further processing. Muscle tissue (mean \pm s.d. $0.09 \pm 0.02 \mathrm{~g}$; range $0.02-0.13 \mathrm{~g}$ ) was dissected from each stickleback by taking a section of the dorsal axial muscle. Water louse collected from each temperature treatment $\left(10^{\circ} \mathrm{C}\right.$ and $20^{\circ} \mathrm{C}$ ) on each sampling day were pooled due to low sample weight before extracting whole-body tissue $(0.05 \pm$ $0.01 \mathrm{~g}$; range 0.03-0.07 g). However, when enough tissue was available, multiple water louse samples were analysed. To each sample, $5 \mathrm{ng}(50 \mu \mathrm{L})$ of the internal standard methylphenidateD9 (Cerilliant, USA; in methanol, HPLC-grade, Fisher Chemical, Loughborough, UK) was added. For both stickleback and water louse, tissues were extracted using $1.5 \mathrm{ml}$ acetonitrile (HPLC-grade, Fisher Chemical, Loughborough, UK) repeated twice (based on the method used by Brodin et al. 2013; McCallum et al. 2017, 2018). The samples were homogenized and extracted for $4 \mathrm{~min}$ at 42,000 oscillations per minute (Mini Beadbeater, Biospec. Bartlesville, USA) with zirconium beads and then centrifuged the samples at $17,500 \mathrm{~g}$ for $10 \mathrm{~min}$ (Beckman Coulter Microfuge 22R Centrifuge). This protocol was used for both eluent mixtures, and the supernatants were combined. The combined supernatants were evaporated to $20 \mu \mathrm{l}$ and the sample was reconstituted in $100 \mu \mathrm{l}$ methanol (HPLC-grade, Fisher Chemical, Loughborough, UK).

Fifty microlitres of methylphenidate-D9 (500 ng/L) was added to $10-\mathrm{ml}$ aliquots of the aqueous samples, filtered (0.45 $\mu \mathrm{m}$, Filtropur S, Sarstedt, N umbrecht, Germany), and acidified with $10 \mu \mathrm{L}$ formic acid $(0.1 \% v / v$, Merck KGaA, Darmstadt, Germany) to a $\mathrm{pH}$ of 2.7 .

All of the samples were injected to an EQuan MAX Plus LCQuantiva triple quadrupole MS/MS (Thermo Scientific, San Jose, USA). A $10-\mu \mathrm{L}$ injection volume was used for stickleback/louse extracts and the calibration curve. For the aqueous samples, and the corresponding calibration curve, a $1-\mathrm{mL}$ injection volume was used and preconcentrated the analytes on an online-connected Oasis HLB column $(2.1 \times 20 \mathrm{~mm}, 15 \mu \mathrm{m}$
Waters, Milford, USA) using column switching (70 s transfer time and $180 \mathrm{~s}$ elution time). Milli-Q ultra-pure water (Millipore) and methanol (Lichrosolv, Hypergrade, Merck) were used as mobile phases (both containing $0.1 \%$ formic acid (Suprapur, Merck KGaA), v/v) together with Hypersil GOLD columns (Thermo Scientific) as stationary phases: guard $(20 \times$ $2.1 \mathrm{~mm}, 3 \mu \mathrm{m})$ and analytical $(50 \times 2.1 \mathrm{~mm}, 3 \mu \mathrm{m})$. The flow rate was kept at $350 \mu \mathrm{L} / \mathrm{min}$, and we used two linear gradients. The gradient for the stickleback/louse extracts were as follows: 0-2 min, methanol 2\%; 2-4 min, methanol 2-100\%; 4-6 min, methanol 100\%; and 6.01-7.5 min, methanol $2 \%$. For the aqueous samples, the gradient was 0-2 min, methanol $2 \%$; $2-$ $4.75 \mathrm{~min}$, methanol 2-100\%; 4.75-7 min, methanol 100\%; and 7.01-9 min, methanol $2 \%$.

Positive polarity and a heated electrospray at $338^{\circ} \mathrm{C}$, an ion transfer tube temperature at $350{ }^{\circ} \mathrm{C}$, and a spray voltage at $3.5 \mathrm{kV}$ were used. The following selected reactionmonitoring (SRM) transitions for quantification ions $(\mathrm{Q})$ and qualitative $(\mathrm{q})$ ions were used: methylphenidate $234.14 \rightarrow$ 84.11 (Q), 56.18 (q); ritalinic acid 220.14 $\rightarrow 84.11$ (Q), 174.18 (q); and methylphenidate-D9 243.2 $\rightarrow 93.17$ (Q), 61.17 (q). A 9-point calibration curve was used from 0.05 to $1000 \mathrm{ng} / \mathrm{g}$ or $\mathrm{ng} / \mathrm{L}\left(r^{2}>0.99\right.$ for both compounds). The first or the second point within the linear range was used for the limits of quantification (LOQ): methylphenidate $1 \mathrm{ng} / \mathrm{L}$ (aqueous) and $0.1 \mathrm{ng} / \mathrm{g}$ (biota); and ritalinic acid $1 \mathrm{ng} / \mathrm{L}$ (aqueous) and $1 \mathrm{ng} / \mathrm{g}$ (biota). See supplementary materials for QA/QC data.

\section{Statistical analyses}

All analyses were conducted in R (version: 3.5.0; R Core Team 2018). The average concentrations of methylphenidate and ritalinic acid in the water column and the uptake of both compounds in tissues were descriptively summarized. Welch's two-sample $t$ tests were used to analyse whether methylphenidate degradation in the water column was impacted by temperature treatment. The halflife of methylphenidate and formation rate of ritalinic acid in water was calculated by plotting the natural log of the concentrations measured versus time of sampling. Degradation/formation rate, $k_{\mathrm{d}}$, is the slope given by a linear regression analysis. Half-life was determined using the following equation:

$$
t_{1 / 2} \text { or } t_{f}=\frac{\ln (2)}{k_{d}}
$$

in which $t_{1 / 2}$ equals the half-life of methylphenidate and $t_{\mathrm{f}}$ equals the formation of ritalinic acid (d) and $k_{\mathrm{d}}$ equals the depuration rate. Relative tissue concentration for both compounds in the stickleback and water louse tissues was calculated using the following equation:

Relative tissue concentration $=\frac{C_{b}}{C_{w}}$ 
where $C_{\mathrm{b}}$ is the methylphenidate/ritalinic acid concentration measured in biota and $C_{\mathrm{w}}$ is the methyl phenidate/ritalinic acid concentration measured in the exposure water. Relative tissue uptake was calculated at each sampling point.

\section{Results}

\section{Fate of methylphenidate and ritalinic acid in the water column}

Methylphenidate quickly hydrolysed to ritalinic acid (Fig. 1a), with ritalinic acid concentrations surpassing methylphenidate concentrations between the 48 and $100 \mathrm{~h}$ in both studies (i.e., water without biota and with biota). Methylphenidate degraded to ritalinic acid and faster at
$20{ }^{\circ} \mathrm{C}$ than at $10{ }^{\circ} \mathrm{C}$; likewise, ritalinic acid formed faster at $20^{\circ} \mathrm{C}$ than at $10^{\circ} \mathrm{C}$ (Table 1 ; Fig. 1b). In both studies, methylphenidate was still detectable in the water column above the LOQ after 2 weeks (Table 1). Temperature did not affect the concentration of methylphenidate immediately after dosing (Fig. 1b, Table 1, Welch two-sample $t$ test, $t_{3.50}=-0.69$, $p=0.54$ ), but on the final day of sampling, the concentration of methylphenidate was higher in $10{ }^{\circ} \mathrm{C}$ tanks than in $20^{\circ} \mathrm{C}$ tanks (Fig. 1b, Table 1: Welch two-sample $t$ test, $t_{2.07}=10.37$, $p=0.0081)$. Concentrations of ritalinic acid did not differ between temperature treatments at the start of the experiment (Welch two-sample $t$ test, $t_{2.20}=0.54, p=0.64$ ) but were higher in $20{ }^{\circ} \mathrm{C}$ tanks than in $10{ }^{\circ} \mathrm{C}$ tanks at the end of the experiment (Welch two-sample $t$ test, $t_{4.00}=-2.86, p=$ 0.046). See Supplementary Materials Fig. S1 ab for increased resolution of sampling across the first $24 \mathrm{~h}$.
Fig. 1 Concentrations of methylphenidate and ritalinic acid in exposure aquaria under (a) static conditions with no biota $\left(N_{\text {tanks }}=1\right)$ and (b) static conditions with biota, facetted by temperature treatment $\left(N_{\text {tanks }}=3\right)$. Each point represents one sample. Solid lines represent the mean fit by a loess curve, with shaded ribbons showing the $95 \%$ confidence interval of the mean

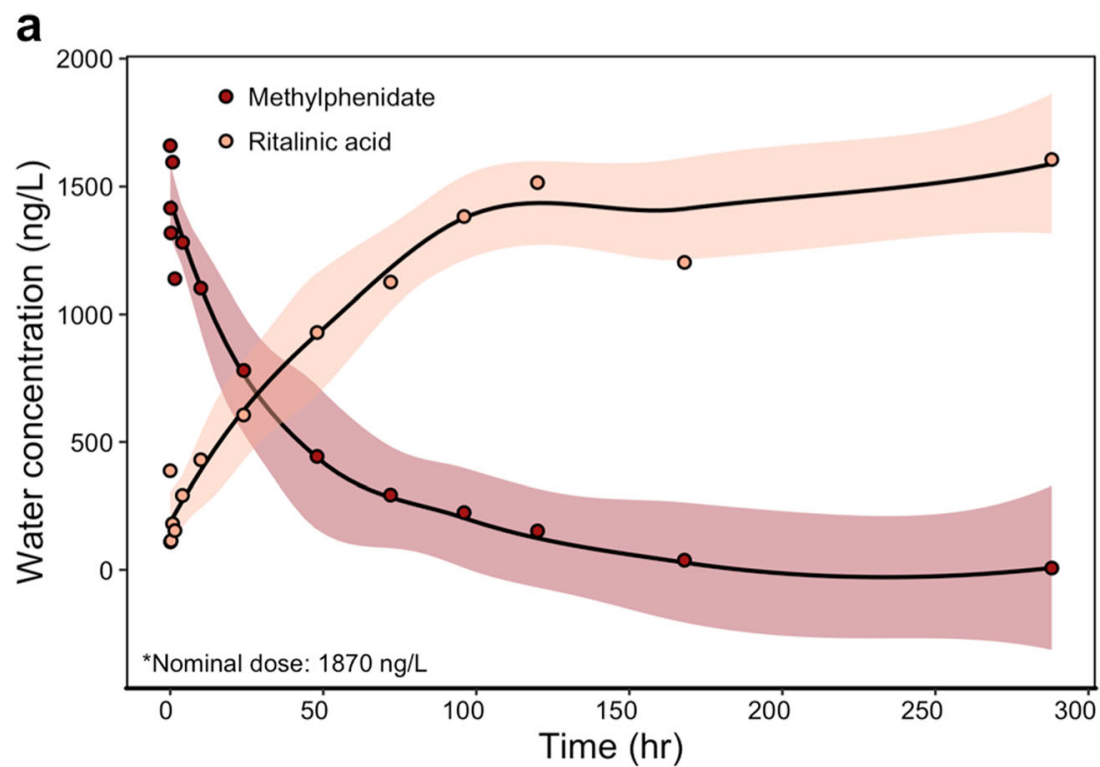

b

$10^{\circ} \mathrm{C}$

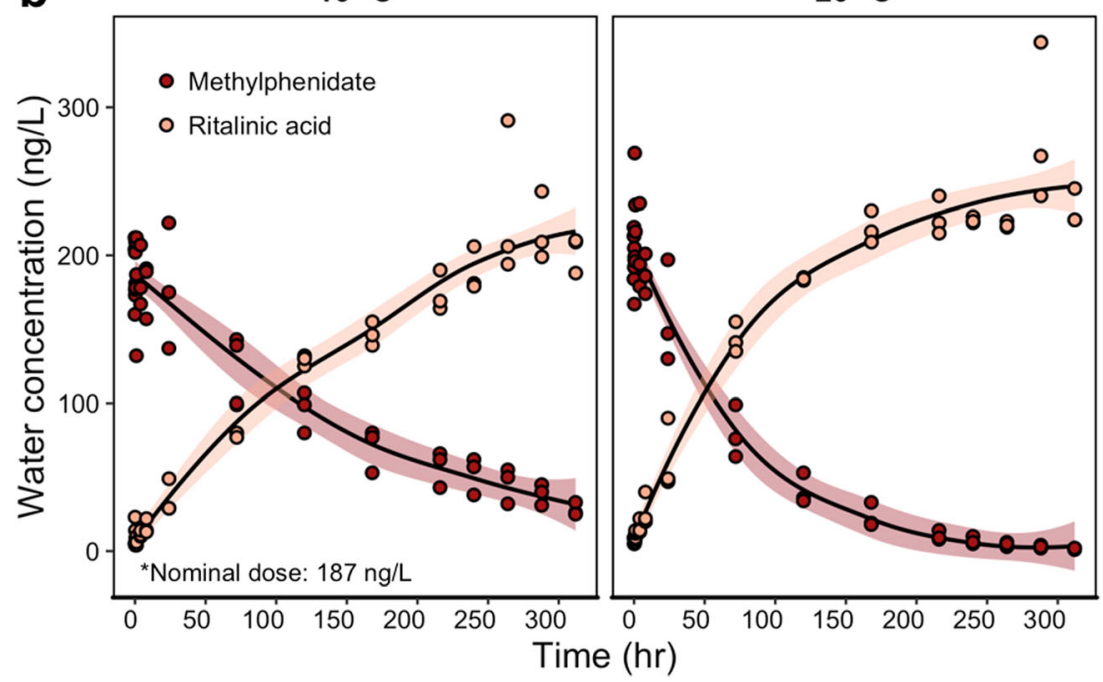


Table 1 Water concentrations (ng/L) of methylphenidate and ritalinic acid from study 1 and study 2, with the half-life or formation rate for methylphenidate or ritalinic acid, respectively. When appropriate, data are shown as mean \pm s.d. Start sampling occurred immediately after dosing. End sampling occurred on the final sampling day. - indicates no data, and tanks were only dosed with methylphenidate

\begin{tabular}{lllll}
\hline & Nominal & Measured start & Measured end & Half-life or formation time (h) \\
\hline $\begin{array}{l}\text { Study 1: static water only, } N_{\text {tanks }}=1 \\
20^{\circ} \mathrm{C} \text { methylphenidate }\end{array}$ & 1870 & & & 37 \\
$20^{\circ} \mathrm{C}$ ritalinic acid & - & 1660 & 1606 & 79 \\
$\begin{array}{l}\text { Study } 2 \text { : static }+ \text { biota, } N_{\text {tanks }}=3 \\
10^{\circ} \mathrm{C} \text { methylphenidate }\end{array}$ & 187 & 387 & & 122 \\
$20^{\circ} \mathrm{C}$ methylphenidate & 187 & $192 \pm 28$ & $28 \pm 4$ & 47 \\
$10^{\circ} \mathrm{C}$ ritalinic acid & - & $205 \pm 19$ & $2 \pm 1$ & 62 \\
$20^{\circ} \mathrm{C}$ ritalinic acid & - & $11 \pm 10$ & $202 \pm 12$ & 65 \\
\hline
\end{tabular}

\section{Uptake in tissues of stickleback and water louse}

Stickleback and water louse took up methylphenidate in their tissues at different rates when exposed under the same experimental conditions (Fig. 2a, b). For stickleback, tissue concentrations of methylphenidate were highest within the first $4 \mathrm{~h}$ of exposure (Fig. 2a) and were not detectable above the LOQ on the last day of sampling. For water louse, tissue concentrations of methylphenidate peaked after 5 to 7 days (Fig. 2b), reached higher tissue concentrations than stickleback, and were still detectable at the end of the experiment (Table 2). Water louse relative tissue concentrations (ratio between tissue and water) were generally higher in the $20^{\circ} \mathrm{C}$ than $10^{\circ} \mathrm{C}$ treatment at the end of the experiment (Table 2, end relative tissue concentration). Neither stickleback nor water louse took up ritalinic acid above the LOQ in their tissues at any sampling point in the experiment (Table 2). See Supplementary Materials Figure S2ab for figure increased resolution of sampling across the first $24 \mathrm{~h}$.

\section{Discussion}

Methylphenidate and ritalinic acid have garnered recent research attention as surface water contaminants and a potential concern for aquatic wildlife (Letzel et al. 2010; Endres et al. 2017). To support future ecotoxicology studies on these compounds, we assessed the degradation of methylphenidate and formation of ritalinic acid in the water column and tissue uptake in two aquatic organisms at two temperatures. The studies were performed well below the $\mathrm{pKa}$ of methylphenidate to avoid issues on ionization that has an impact on tissue uptake (Armitage et al. 2013) but also on adsorption processes (Rybacka and Andersson 2016). Methylphenidate hydrolyzed to ritalinic acid in the water column faster at $20^{\circ} \mathrm{C}$ than $10{ }^{\circ} \mathrm{C}$ ( $37 \mathrm{~h}$ versus $122 \mathrm{~h}$, Table 1) because higher temperatures increase the rate of the physicochemical processes leading to the transformation. Additionally, the degradation of methylphenidate to ritalinic acid was similar in exposure tanks with or without aquatic biota. The $\mathrm{pKa}$ of ritalinic acid is low (3.5; SciFinder) and the deprotonated form will thus dominate in our experimental setting, which typically lowers the uptake and drives the lack of uptake of this metabolite (Fu et al. 2009).

The uptake and depuration of methylphenidate in stickleback muscle tissue closely resembled that of human and rhesus macaque uptake and depuration following oral administration: a peak in plasma within 1-4 h followed by rapid depuration (Gualtieri et al. 1982; Doerge et al. 2000). Future ecotoxicological studies on methylphenidate using fish should carefully plan dosing and endpoint measurement considering compound degradation in the water column and rapid uptake in tissues. Studies to date, for example, Endres et al. (2017) and De Serrano et al. (2016), exposed fish for less than an hour and then measured physiological or behavioural endpoints. Our findings indicate that methylphenidate concentrations stay above $180 \mathrm{ng} / \mathrm{L}$ (the concentration that Endres et al. (2017) found increased on zebrafish cortisol) in the water column for up to 2 days. It would be valuable to understand how methylphenidate affects fish physiology and behaviour over a longer ( $48 \mathrm{~h}$ ) timespan. We assessed methylphenidate in muscle tissues, but it would also be fruitful to compare uptake across different tissue types in fish because pharmaceuticals can bioconcentrate differentially among tissues (e.g., Tanoue et al. 2015). However, in general, the low observed uptake fits well with the calculated bioconcentration factors.

In contrast, water louse did not reach peak methylphenidate concentrations until 5-7 days following the initial exposure, depending on temperature. This indicates that water louse may have different rates or mechanisms of uptake and/or different means of metabolizing or eliminating methylphenidate. In humans, methylphenidate is metabolized to ritalinic acid primarily by carboxylesterase CES1A1 (Markowitz and Patrick 2001). The role of carboxylesterases in fish and invertebrate methylphenidate metabolism (and their comparative differences) was beyond the scope of this experiment but could be 
Fig. 2 Methylphenidate concentrations in (a) muscle tissue from stickleback and (b) whole-body tissue from water louse, plotted against sampling time. Separate trend lines denote two temperature treatments. Error bars represent \pm 1 standard error. Stickleback, $N_{\text {samples }}=3-6$ per sampling time; water louse,

$N_{\text {samples }}=1-3$ per sampling time. Sample size varies due to mass of organisms collected a

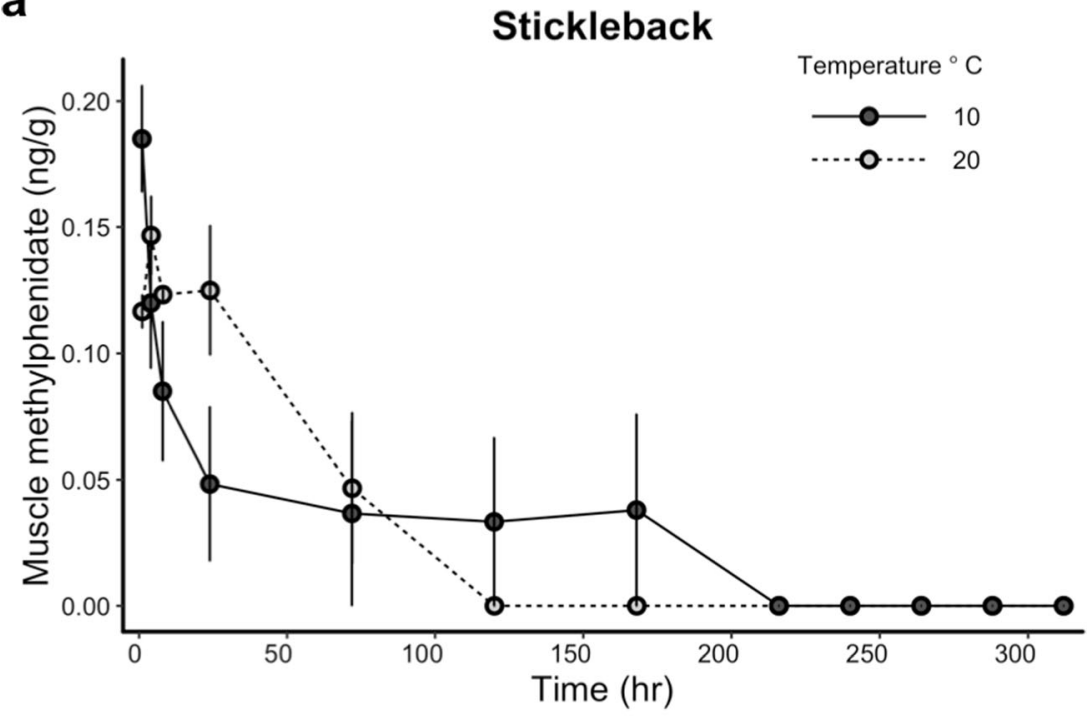

b

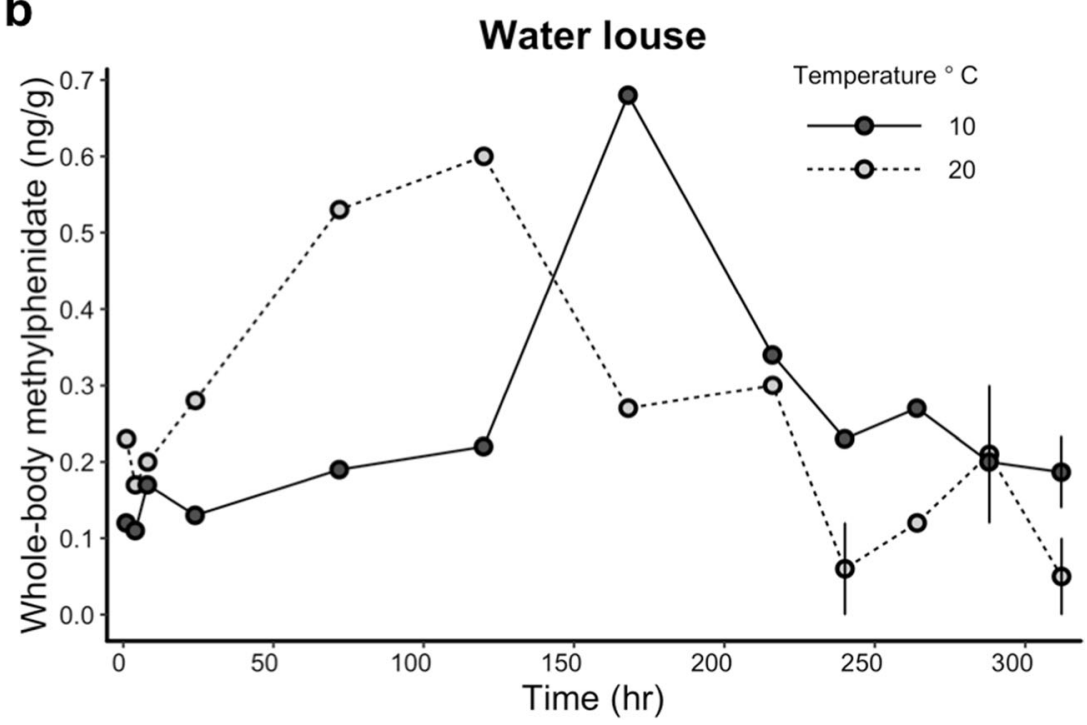

Table 2 Tissue concentrations (ng/g) and relative tissue concentrations (eq. 2) of methylphenidate and ritalinic acid in stickleback and water louse from study 2. Start sampling occurred $60 \mathrm{~min}$ after dosing. Values are shown as mean \pm s.d. (range). Ranges are not given for single values. End sampling occurred on the final sampling day. $L O Q$ limit of quantification, $N A$ not applicable

Start $(\mathrm{ng} / \mathrm{g}) \quad$ Start relative tissue concentration $\quad$ End $(\mathrm{ng} / \mathrm{g}) \quad \begin{aligned} & \text { End relative tissue } \\ & \text { concentration }\end{aligned}$

\begin{tabular}{|c|c|c|c|c|}
\hline \multicolumn{5}{|l|}{ Stickleback (muscle tissue) } \\
\hline $10^{\circ} \mathrm{C}$ methylphenidate & $0.18 \pm 0.05(0.13-0.28)$ & $1.2 \pm 0.5(0.7-2.1)$ & $<$ LOQ & NA \\
\hline $20{ }^{\circ} \mathrm{C}$ methylphenidate & $0.12 \pm 0.02(0.10-0.14)$ & $0.5 \pm 0.1(0.4-0.7)$ & $<$ LOQ & NA \\
\hline $10{ }^{\circ} \mathrm{C}$ ritalinic acid & $<$ LOQ & NA & $<$ LOQ & NA \\
\hline $20{ }^{\circ} \mathrm{C}$ ritalinic acid & $<$ LOQ & NA & $<\mathrm{LOQ}$ & NA \\
\hline \multicolumn{5}{|l|}{ Water louse (whole-body) } \\
\hline $10^{\circ} \mathrm{C}$ methylphenidate & 0.1 & 0.6 & $0.2 \pm 0.1(0.1-0.3)$ & $7.5 \pm 3.2(4.0-10.4)$ \\
\hline $20{ }^{\circ} \mathrm{C}$ methylphenidate & 0.2 & 1.1 & 0.1 & 50.0 \\
\hline $10{ }^{\circ} \mathrm{C}$ ritalinic acid & $<$ LOQ & NA & $<$ LOQ & NA \\
\hline $20{ }^{\circ} \mathrm{C}$ ritalinic acid & $<$ LOQ & NA & $<\mathrm{LOQ}$ & NA \\
\hline
\end{tabular}


a focus of future studies. Aquatic invertebrates have previously been shown to bioconcentrate certain pharmaceuticals more than vertebrates and can generally have different patterns in uptake and depuration (Meredith-Williams et al. 2012; Fong and Ford 2014; Heynen et al. 2016). For example, Lagesson et al. (2016) noted that water louse bioconcentrated higher levels of oxazepam, diphenhydramine, and hydroxyzine when compared to European perch (Perca fluviatilis) exposed in naturalistic pond experiment. However, these chemicals are more hydrophobic than methylphenidate which may imply more uptake via food and particulate matter. Future work should investigate any behavioural and/or physiological effects following exposure to environmentally relevant concentration of methylphenidate in aquatic invertebrates. Changes in invertebrate behaviour can have important consequences for trophic transfer of pollutants if they are more susceptible to predation (e.g., Weis et al. 2001).

In conclusion, we have provided the first analysis of the degradation and uptake of methylphenidate and ritalinic acid under controlled conditions in a geographically widespread aquatic vertebrate and invertebrate. Generally, methylphenidate appears to be of greater concern for aquatic invertebrates based on tissue uptake patterns. Concentrations of the primary metabolite, ritalinic acid, are relatively high in wastewater effluents $(50-300 \mathrm{ng} / \mathrm{L})$, but the fish and invertebrates in our study did not have detectable tissue concentrations of ritalinic acid. The above findings (e.g. half-life, tissue uptake) will be helpful for designing future ecotoxicological studies investigating the biological impacts (e.g. behaviour, physiology) of methylphenidate and ritalinic acid in aquatic systems.

Acknowledgments The authors would like to thank Daniel Cerveny and Anna Sundelin for field and laboratory assistance.

Funding information Financial support was provided by ÅForsk Foundation.

Compliance with ethical standards All methods and animal handling was approved under ethical permit number Dnr A-8-15 to T. Brodin.

Data availability All data are available via contact with the corresponding author.

Open Access This article is distributed under the terms of the Creative Commons Attribution 4.0 International License (http:// creativecommons.org/licenses/by/4.0/), which permits unrestricted use, distribution, and reproduction in any medium, provided you give appropriate credit to the original author(s) and the source, provide a link to the Creative Commons license, and indicate if changes were made.

Publisher's note Springer Nature remains neutral with regard to jurisdictional claims in published maps and institutional affiliations.

\section{References}

Armitage JM, Arnot JA, Wania F, Mackay D (2013) Development and evaluation of a mechanistic bioconcentration model for ionogenic organic chemicals in fish. Environ Toxicol Chem 32:115-128. https://doi.org/10.1002/etc.2020

Bean TG, Rattner BA, Lazarus RS, Day DD, Burket SR, Brooks BW, Haddad SP, Bowerman WW (2018) Pharmaceuticals in water, fish and osprey nestlings in Delaware River and bay. Environ Pollut 232: 533-545. https://doi.org/10.1016/j.envpol.2017.09.083

Boxall ABA, Rudd MA, Brooks BW, Caldwell DJ, Choi K, Hickmann S, Innes E, Ostapyk K, Staveley JP, Verslycke T, Ankley GT, Beazley $\mathrm{KF}$, Belanger SE, Berninger JP, Carriquiriborde P, Coors A, DeLeo PC, Dyer SD, Ericson JF, Gagné F, Giesy JP, Gouin T, Hallstrom L, Karlsson MV, Larsson DGJ, Lazorchak JM, Mastrocco F, McLaughlin A, McMaster ME, Meyerhoff RD, Moore R, Parrott JL, Snape JR, Murray-Smith R, Servos MR, Sibley PK, Straub JO, Szabo ND, Topp E, Tetreault GR, Trudeau VL, van der Kraak G (2012) Pharmaceuticals and personal care products in the environment: what are the big questions? Environ Health Perspect 120(9): 1221-1229. https://doi.org/10.1289/ehp.1104477

Brodin T, Fick J, Jonsson M, Klaminder J (2013) Dilute concentrations of a psychiatric drug alter behaviour of fish from natural populations. Science. 339(6121):814-815. https://doi.org/10.1126/science. 1226850

Brodin T, Piovano S, Fick J, Klaminder J, Heynen M, Jonsson M (2014) Ecological effects of pharmaceuticals in aquatic systems - impacts through behavioural alterations. Philos Trans R Soc B Biol Sci 369: 20130580. https://doi.org/10.1098/rstb.2013.0580

Burgard DA, Fuller R, Becker B, Ferrell R, Dinglasan-Panlilio MJ (2013) Potential trends in attention deficit hyperactivity disorder (ADHD) drug use on a college campus: wastewater analysis of amphetamine and ritalinic acid. Sci Total Environ 450-451:242-249. https://doi. org/10.1016/j.scitotenv.2013.02.020

Calisto V, Esteves VI (2009) Psychiatric pharmaceuticals in the environment. Chemosphere. 77(10):1257-1274. https://doi.org/10.1016/j. chemosphere.2009.09.021

Chai G, Governale L, McMahon AW, Trinidad JP, Staffa J, Murphy D (2012) Trends of outpatient prescription drug utilization in US children, 2002-2010. Pediatrics. 130(1):23-31. https://doi.org/10.1542/ peds.2011-2879

Concerta Prescribing Information (2013) :1-32. Janssen Pharmaceuticals Inc. revised December 2013. Available at https://www.janssenmd. com/pdf/concerta/concerta_pi.pdf. Accessed 14 Sept 2018

Core Team R (2018) R: a language and environment for statistical computing. R Foundation for Statistical Computing, Vienna

de Serrano AR, Fong C, Rodd FH (2016) Effects of methylphenidate on responses to novelty in a teleost fish (Poecilia reticulata). Behav Brain Res 302:53-59. https://doi.org/10.1016/j.bbr.2016.01.021

Doerge DR, Fogle CM, Paule MG, McCullagh M, Bajic S (2000) Analysis of methylphenidate and its metabolite ritalinic acid in monkey plasma by liquid chromatography/electrospray ionization mass spectrometry. Rapid Commun Mass Spectrom 14(8):619-623. https://doi.org/10.1002/(SICI)1097-0231(20000430)14:8<619:: AID-RCM916>3.0.CO;2-2

Du B, Price AE, Scott WC, Kristofco LA, Ramirez AJ, Chambliss CK, Yelderman JC, Brooks BW (2014) Comparison of contaminants of emerging concern removal, discharge, and water quality hazards among centralized and on-site wastewater treatment system effluents receiving common wastewater influent. Sci Total Environ 466467:976-984. https://doi.org/10.1016/j.scitotenv.2013.07.126

Endres HC, Kabaselle C, Bertol CD, Rossato-Grando LG, da Rosa JG, Barcellos HH, Gil Barcellos LJ, Barcellos HH, Gil Barcellos LJ, Gil Barcellos LJ (2017) First evidence that waterborne methylphenidate alters endocrine and behavioral stress responses in zebrafish. 
Neurosci Lett 650:114-117. https://doi.org/10.1016/j.neulet.2017. 04.039

Faraj BA, Israili ZH, Perel JM, Jenkins ML, Holtzman SG, Cucinell SA, Dayton PG (1974) Metabolism and disposition of methylphenidate14C: studies in man and animals. J Pharmacol Exeperimental Ther 191(8):535-547

Fong PP, Ford AT (2014) The biological effects of antidepressants on the molluscs and crustaceans: a review. Aquat Toxicol 151:4-13. https://doi.org/10.1016/j.aquatox.2013.12.003

Fu W, Franco A, Trapp S (2009) Methods for estimating the bioconcentration factor of ionizable organic chemicals. Environ Toxicol Chem 28:1372-1379. https://doi.org/10.1897/08-233.1

Gualtieri CT, Wargin W, Kanoy R, Patrick K, Shen CD, Youngblood W, Mueller RA, Breese GR (1982) Clinical studies of methylphenidate serum levels in children and adults. J Am Acad Child Psychiatry 21(1):19-26. https://doi.org/10.1097/00004583-198201000-00005

Gunnarsson L, Jauhiainen A, Kristiansson E, Nerman O, Larsson DGJ (2008) Evolutionary conservation of human drug targets in organisms used for environmental risk assessments. Environ Sci Technol 42(15):5807-5813. https://doi.org/10.1021/es8005173

Heynen M, Fick J, Jonsson M, Klaminder J, Brodin T (2016) Effect of bioconcentration and trophic transfer on realized exposure to oxazepam in 2 predators, the dragonfly larvae (Aeshna grandis) and the Eurasian perch (Perca fluviatilis). Environ Toxicol Chem 35(4): 930-937. https://doi.org/10.1002/etc.3368

Lagesson A, Fahlman J, Brodin T, Fick J, Jonsson M, Byström P, Klaminder J (2016) Bioaccumulation of five pharmaceuticals at multiple trophic levels in an aquatic food web - insights from a field experiment. Sci Total Environ 568:208-215. https://doi.org/10. 1016/j.scitotenv.2016.05.206

Letzel M, Weiss K, Schüssler W, Sengl M (2010) Occurrence and fate of the human pharmaceutical metabolite ritalinic acid in the aquatic system. Chemosphere. 81(11):1416-1422. https://doi.org/10.1016/ j.chemosphere.2010.09.018

Levin ED, Sledge D, Roach S, Petro A, Donerly S, Linney E (2011) Persistent behavioral impairment caused by embryonic methylphenidate exposure in zebrafish. Neurotoxicol Teratol 33(6):668-673. https://doi.org/10.1016/j.ntt.2011.06.004

Markowitz JS, Patrick KS (2001) Pharmacokinetic and pharmacodynamic drug interactions in the treatment of attention-deficit hyperactivity disorder. Clin Pharmacokin 40(10):753-772. https://doi.org/10. 2165/00003088-200140100-00004

McCabe SE, Knight JR, Teter CJ, Wechsler H (2005) Non-medical use of prescription stimulants among US college students: prevalence and correlates from a national survey. Addiction. 100(1):96-106. https:// doi.org/10.1111/j.1360-0443.2004.00944.x

McCallum ES, Krutzelmann E, Brodin T, Fick J, Sundelin A, Balshine S (2017) Exposure to wastewater effluent affects fish behaviour and tissue-specific uptake of pharmaceuticals. Sci Total Environ 605: 578-588. https://doi.org/10.1016/j.scitotenv.2017.06.073

McCallum ES, Sundelin S, Fick J, Alanärä A, Klaminder J, Hellström G, Brodin T (2018) Investigating tissue bioconcentration and the behavioural effects of two pharmaceutical pollutants on sea trout (Salmo trutta) in the laboratory and field. Aquat Toxicol 207:170 178. https://doi.org/10.1016/j.aquatox.2018.11.028

Meredith-Williams M, Carter LJ, Fussell R, Raffaelli D, Ashauer R, Boxall ABA (2012) Uptake and depuration of pharmaceuticals in aquatic invertebrates. Environ Pollut 165:250-258. https://doi.org/ 10.1016/j.envpol.2011.11.029

Oliveira TS, Murphy M, Mendola N, Wong V, Carlson D, Waring L (2015) Characterization of pharmaceuticals and personal care products in hospital effluent and waste water influent/effluent by directinjection LC-MS-MS. Sci Total Environ 518-519:459-478. https:// doi.org/10.1016/j.scitotenv.2015.02.104

Rybacka A, Andersson PL (2016) Considering ionic state in modelling sorption of pharmaceuticals to sewage sludge. Chemosphere. 165: 284-293. https://doi.org/10.1016/j.chemosphere.2016.09.014

Saaristo M, Brodin T, Balshine S, Bertram MG, Brooks BW, Ehlman SM, McCallum ES, Sih A, Sundin J, Wong BB, Arnold KE (2018) Direct and indirect effects of chemical contaminants on the behaviour, ecology and evolution of wildlife. Proc R Soc B 285(1885): 20181297. https://doi.org/10.1098/rspb.2018.1297

SciFinder, Chemical Abstracts Service. URL: https://scifinder.cas.org . Accessed 28 Nov 2018

Tanoue R, Nomiyama K, Nakamura H, Kim JW, Isobe T, Shinohara R, Kunisue T, Tanabe S (2015) Uptake and tissue distribution of pharmaceuticals and personal care products in wild fish from treatedwastewater-impacted streams. Environ Sci Technol. 49(19):1164911658. https://doi.org/10.1021/acs.est.5b02478

US EPA EPISuite (n.d.) (Estimation Programs Interface Suite ${ }^{\mathrm{TM}}$ ) for Microsoft ${ }^{\circledR}$ Windows, v 4.11. United States Environmental Protection Agency, Washington, DC, USA

van der Aa M, Bijlsma L, Emke E, Dijkman E, van Nuijs ALN, van de Ven B, Hernández F, Versteegh A, de Voogt P (2013) Risk assessment for drugs of abuse in the Dutch watercycle. Water Res 47(5): 1848-1857. https://doi.org/10.1016/j.watres.2013.01.013

Volkow ND, Fowler JS, Wang G, Ding Y, Gatley SJ (2002) Mechanism of action of methylphenidate: insights from PET imaging studies. J Atten Disord. 6 Suppl 1(FEBRUARY 2002):S31-S43. https://doi. org/10.1177/070674370200601S05

Watkins CD, Winemiller KO, Mora MA, Du B, Chambliss CK, Brooks BW, Phalen D (2014) Assessment of mosquitofish (Gambusia affinis) health indicators in relation to domestic wastewater discharges in suburbs of Houston, USA. Bull Environ Contam Toxicol 93(1):13-18. https://doi.org/10.1007/s00128-014-1248-z

Weis JS, Smith G, Zhou T, Santiago-Bass C, Weis P (2001) Effects of contaminants on behavior: biochemical mechanisms and ecological consequences. Bioscience. 51(3):209. https://doi.org/10.1641/00063568(2001)051[0209:EOCOBB]2.0.CO;2 